\title{
GAS TURBINE PERFORMANCE ANALYSIS OPERATING WITH LOW HEATING VALUE FUELS
}

\author{
E. B. Silva ${ }^{a}$, \\ C. Bringhenti ${ }^{a}$, \\ M. Assato ${ }^{\text {, }}$, \\ and R. C. $\operatorname{Lima}^{c}$ \\ ${ }^{a}$ Instituto Tecnológico de Aeronáutica (ITA) \\ Divisão de Eng. Mecânica e Aeronáutica \\ Praça Marechal do Ar Eduardo Gomes, 50 \\ São José dos Campos, São Paulo, Brasil \\ CEP 12228-900 \\ ${ }^{\mathrm{b}}$ Universidade Federal de Juiz de Fora (UFJF) \\ Dep. de Engenharia de Produção e Mecânica \\ Rua José Lourenço Kelmer, \\ Juiz de Fora, Minas Gerais, Brasil \\ ${ }^{\mathrm{c}}$ Empresa Brasileira de Aeronáutica S.A. \\ (EMBRAER), Av. Brig. Faria Lima, 2170, \\ São José dos Campos, São Paulo, Brasil
}

Received: October 25, 2013 Revised: December 10, 2013 Accepted December 20, 2013

\section{ABSTRACT}

Usually, power plants work with gas turbine designed to fire natural gas; however, there are possibilities to use other types of gaseous fuels with different calorific values that may be available close to the power plant site. These fuels can be gases obtained from steel (from blast furnaces and coking plants), from gasification processes of coal or biomass, among others. In this work, a gas turbine performance was evaluated at different operational conditions in order to verify the technical feasibility of burning low calorific value fuels. A gas turbine designed to operate with natural gas was used as a reference, the model was built and the performance evaluated at design and off-design conditions using a commercial computer program, GasTurb $11^{\circledR}$. A good agreement was obtained between the model operating with natural gas and the available data from open literature, at design and off-design conditions. The model was simulated using low heating value fuels under the same conditions established for natural gas. A reduction in compressor's surge margin was identified when using low heating value fuels as well as an increase in power output. Therefore, for safe operation a strategy for recovering the surge margin was adopted. In this study the control strategy adopted was bleed air at the compressor discharge. This control strategy presents a technical viability and ensures that the gas turbine operates with the same surge margin level as when using natural gas.

Keywords: low heating value fuels, gas turbine, performance, simulation

\section{NOMENCLATURE}

GGT

HR

LHV

NGV

PW

SGTM

$\mathrm{T}$

$P$

W

WF

\section{Greek symbols}

$\eta$

efficiency

\section{Subscripts}

$\begin{array}{ll}2 & \text { inlet compressor } \\ 8 & \text { exhaust duct } \\ \text { COOL } & \text { cooling } \\ \text { CORR } & \text { corrected } \\ \text { F } & \text { fuel } \\ \text { NET } & \text { liquid } \\ \text { STD } & \text { standard } \\ \text { ds } & \text { design }\end{array}$

\section{INTRODUCTION}

In a broad sense, gas turbines are engines which use the thermal energy from the combustion process, mixing and burning air and fuel, to generate shaft power for industrial and aeronautical applications or thrust for jet propulsion in aircraft engines (Baskharone, 2006; Walsh and Fletcher, 2004; Saravanamuttoo et al., 2001). Usually, industrial gas turbines are designed to operate with a specific fuel, typically natural gas or diesel. However, others types of fuels may be available near the power plant sites, such as residual (from blast furnace, for example) or renewable fuels (as biomass gasification), which despite its low heating value they may represent a major operational cost reduction due to its lower costs. Researchers are working in gas turbine that can operate with multi fuels, with the possibility of using low calorific value fuels, but looking for the technical problems reduction, assuring economic viability and environmental issues (Ernst, 2011).

There is a growing demand for new fuel sources, such as ethanol, biodiesel from vegetable sources, and gas fuels derived from the gasification process of biomass (Higman and Van der Burgt, 2007). Nowadays, the use of renewable or waste fuels (use of waste gases in industrial processes) has 
attracted attention due to the economic advantages. In some cases, the renewable fuels production of low cost, and therefore its use for electric power generation, in isolated communities can provide income generation and regional development, beyond the environment appeal in relation to reducing emissions of pollutants. There is extensive research devoted to the use of alternative fuels, refinery waste gases, products of gasification processes or industrial by-products, all of them are being evaluated in terms of availability and adaptability. All these fuels have low heating value, but the associated reduced cost is an advantage that may be compensatory. In combined cycle plants gas turbines are essential and therefore the low heating value fuels (LHV) present alternatives both economically and to replace natural gas in the event of missing it. Since, fuel corresponds to the largest portion of the operational cost, using alternative and low-cost fuels may be a good strategy for increasing the power plants competitiveness.

Palmer et al. (1993) conducted a performance investigation with the GE LM2500 firing low heating value biomass-derived fuels and air supplied from the gas turbine compressor. The simulations were made using GateCycle ${ }^{\circledR}$ software for performance analysis at design and off-design point. Three different fuels were investigated: two using different fuel gases, and one using low Btu fuel gas as well as steam injection up to the control limit. The performance changing with fuels and also compressor inlet temperature were presented. The model employed compressor map data and incorporated the control principles behind gas turbine operation in order to accurately predict variations in performance. The results showed that there was an increase in mass flow of air and fuel, efficiency and power with the use of fuels of lower LHV. Furthermore, the compressor surge margin was decreased and thus, the operation requires careful because the operating line must not exceed the compressor surge line.

Palmer and Erbes (1994) simulated the GE FRAME 6 gas turbine in several different operation conditions, even without having the data available in its entirety. This is a common situation when you want to do a priori assessment of the expected behavior of the engine which will be subjected to various non-standard conditions. The operational behavior can be estimated having the preliminary performance data available, which will provide a basis for a thermal, as well as a more cost evaluation. In the study performed, some strategies were used to allow the gas turbine to operate with low LHV fuels. Thus, one of the strategies used were bleed almost $15 \%$ of the air from the compressor to recover the surge margin; the bled air was directed to the gasification process. The simulations were made changing the fuels, low LHV, and ambient temperature at off-design. With regard to industrial turbines, which essentially operate without interruption for over 15 years, this significantly affects the costs.

This study used as a generic single shaft gas turbine (named GGT) designed to operate with natural gas. The model was built using GasTurb $11^{\circledR}$ (Kurzke, 2007) and the performance at design and off-design operation conditions compared with available data in open literature. After that, a performance and operational analysis characteristics firing two low heating value fuels in distinct working conditions was done. The main goal is to analyze the operational behavior of the GGT operating with low heating value fuels. A control strategy was used to ensure safe operation.

\section{GAS TURBINE PERFORMANCE}

The single shaft gas turbine (GGT) used in this work is composed of an axial compressor equipped with a bleed air in its discharge, an annular combustion chamber and an axial turbine with the first stage cooled.

Figure 1 shows the representative single shaft gas turbine configuration and its thermodynamics stations assumed herein. The nomenclatures are based on the international standard SAE AS 755-D.

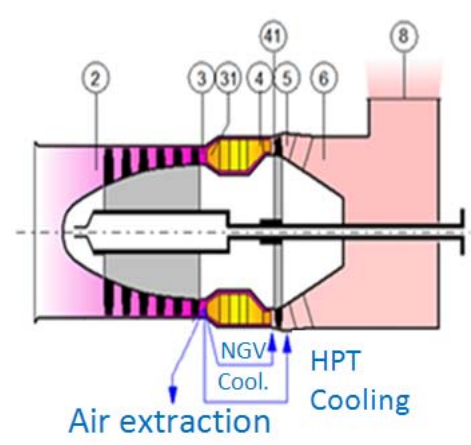

\begin{tabular}{cl}
\hline Sections & Descriptions \\
\hline 2 & Compressor inlet \\
3 & Compressor exit \\
31 & Combustion chamber inlet \\
4 & Combustion chamber exit \\
41 & Turbine rotor inlet \\
5 & Turbine exit \\
6 & Turbine diffuser exit \\
8 & Exhaust duct \\
\hline
\end{tabular}

Figure 1. Typical single shaft gas turbine (Kurzke, 2007).

The performance parameters of the GGT operating with natural gas and general specifications are presented in Table 1. Further information such as: compressor and turbine isentropic efficiencies, combustion chamber pressure loss, combustion chamber exit temperature, compressor bleed percentage, mechanical efficiency and generator efficiency were assumed to build the computational 
model in order to achieve the same design point data from literature. This data will be presented in methodology section.

Table 1. Generic Single Shaft Gas Turbine (GGT) data, ISO conditions [Solar Turbines, 2009].

\begin{tabular}{lccl||l}
\hline Performance & & & & General specifications \\
\hline \hline Output Power & PW & 3,515 & $\mathrm{~kW}_{\mathrm{e}}$ & $\begin{array}{l}\text { Axial Compressor } \\
-11 \text { stages }\end{array}$ \\
$\begin{array}{l}\text { Heat Rate } \\
\text { Engine }\end{array}$ & $\mathrm{HR}$ & 12,920 & $\mathrm{~kJ} / \mathrm{kW}_{\mathrm{e}}$-hr & - - inlet airflow $=18.4 \mathrm{~kg} / \mathrm{sec}$ \\
Efficiency & $\eta_{\mathrm{GGT}}$ & 27.86 & $\%$ & - Pressure ratio: $9.7: 1$ \\
Exhaust flow & W8 & 19.0 & $\mathrm{~kg} / \mathrm{sec}$ & $\begin{array}{l}\text { Axial Turbine } \\
-3 \text { stages } \\
\text { Exhaust temp. }\end{array}$ \\
\hline
\end{tabular}

Nominal rating - ISO, at $15^{\circ} \mathrm{C}$, sea level, relative humidity $60 \%$

No inlet/exhaust losses; Natural gas with LHV $=48 \mathrm{MJ} / \mathrm{kg}$; No accessory losses

The values at off-design conditions of GGT used to adjust the model are shown in Table 2.

Table 2. Generic Gas Turbine (GGT) off-design data [Solar Turbine, 2009].

\begin{tabular}{ccccccc}
\hline T2 & T2 & PW & HR & HR & $\boldsymbol{\eta}_{\mathbf{G G T}}$ & $\mathbf{W F}$ \\
\hline$\left[{ }^{\circ} \mathrm{C}\right]$ & {$[\mathrm{K}]$} & {$[\mathrm{kW}]$} & {$[\mathrm{Btu} / \mathrm{kW}-\mathrm{h}]$} & {$[\mathrm{kJ} / \mathrm{kW}-\mathrm{h}]$} & {$[-]$} & {$[\mathrm{kg} / \mathrm{s}]$} \\
\hline-7.5 & 265.65 & 4056 & 11890 & 12544.6 & 0.2870 & 0.29445 \\
0 & 273.15 & 3885 & 11990 & 12650.1 & 0.2846 & 0.28441 \\
8 & 281.15 & 3694 & 12120 & 12787.3 & 0.2815 & 0.27336 \\
15 & 288.15 & 3515 & 12246 & 12920.2 & 0.2786 & 0.26282 \\
23 & 296.15 & 3320 & 12470 & 13156.5 & 0.2736 & 0.25278 \\
30 & 303.15 & 3152 & 12690 & 13388.6 & 0.2689 & 0.24422 \\
37.5 & 310.65 & 2970 & 12980 & 13694.6 & 0.2629 & 0.23538 \\
43 & 316.15 & 2820 & 13260 & 13990.0 & 0.2573 & 0.22831 \\
\hline
\end{tabular}

Note 1: All pressures and temperatures described in the present work represent total or stagnation values. The static values will be mentioned in the text, for example, as static pressure (PS) and static temperature (TS).

$$
\begin{aligned}
& \text { Engine Net Efficiency }=\eta_{G G T}[-]=\frac{3600}{H R[k J / k W h]} \\
& \text { Fuel flow }=W F[k g / s]=\frac{P W[k W]}{\eta_{G G T}[-]^{*} L H V[k J / k g]}
\end{aligned}
$$

Engine efficiency and fuel flow varying with ambient temperature (T2) were obtained in function of heat rate and output power as well, Eq. (1) and (2).

The chemical compositions of the two low heating value fuels used in this work was based on Palmer et al. (1993). The lower LHV for both fuels, Fuel 1 and Fuel 2, are 4,867.4 kJ/kg and 5,266.3 $\mathrm{kJ} / \mathrm{kg}$, respectively.

The fuel compositions in mole percentages are:

Fuel 1: $11.86 \% \mathrm{H}_{2} ; 17.69 \% \mathrm{CO} ; 11.00 \% \mathrm{CO}_{2}$; $4.22 \% \mathrm{CH}_{4} ; 0.59 \% \mathrm{C}_{2} \mathrm{H}_{4} ; 15.43 \% \mathrm{H}_{2} \mathrm{O} ; 39.16 \% \mathrm{~N}_{2}$;
$0.05 \% \mathrm{NH}_{3}$

Fuel 2: $12.42 \% \mathrm{H}_{2} ; 18.55 \% \mathrm{CO} ; 11.62 \% \mathrm{CO}_{2}$; $4.42 \% \mathrm{CH}_{4} ; 0.62 \% \mathrm{C}_{2} \mathrm{H}_{4} ; 11.29 \% \mathrm{H}_{2} \mathrm{O} ; 41.08 \% \mathrm{~N}_{2}$; $2.9 \mathrm{e}-7 \% \mathrm{NH}_{3}$.

\section{METHODOLOGY}

Creating a test bench that is required for gas turbines is expensive and so are the operational costs that are involved in performing the necessary tests. Therefore, to minimize the development costs in an effective manner, it is necessary to develop analytical tools, which permit a study of the engine behavior before its production, preventing possible malfunctions or design problems. The gas turbine performance computational models can provide engine performance results with certain accuracy. Nevertheless, the lack of information provided by manufacturers is one of the problems for creating high fidelity gas turbine models. The majority of the data are kept in safety, since it is linked to proprietary knowledge. Thus, to perform design point simulations some values must be guessed by a trial and error procedure. The model calibration process is extremely important to obtain accurate simulations data. Table 3 shows data employed to build the SGTM design point performance model. The percentage of the bled air at compressor discharge was set as $10 \%$ of $\mathrm{W} 2$, being $4 \%$ for the $\mathrm{NGV}$ cooling and $6 \%$ for cooling cavities, discs, platforms, etc.

Table 3. Performance data at design point adopted in this study.

\begin{tabular}{llll}
\hline Description & Nomenc. & Values & Units \\
\hline \hline Inlet air mass flow & W2 & 18.400 & {$[\mathrm{~kg} / \mathrm{s}]$} \\
Corrected air mass flow & W2Rstd & 18.435 & {$[\mathrm{~kg} / \mathrm{s}]$} \\
Inlet air temperature & T1, T2 & 288.15 & {$[\mathrm{~K}]$} \\
Inlet air pressure & P1, P2 & 101.325 & {$[\mathrm{kPa}]$} \\
Pressure ratio & PR & 9.7 & {$[-]$} \\
Comp. exit temperature & T3 & 590.70 & {$[\mathrm{~K}]$} \\
Comp. isent. efficiency & $\eta_{\text {isen-c }}$ & 85.2 & {$[\%]$} \\
Comp. polyt. efficiency & $\eta_{\text {poli-c }}$ & 89.0 & {$[\%]$} \\
Rotational speed & $\mathrm{N}$ & 14,950 & {$[\mathrm{rpm}]$} \\
Bleed percentage & $\mathrm{Bleed}$ & 10 & {$[\%]$} \\
Bleed flow & $\mathrm{Bleed}$ & 1.84 & {$[\mathrm{~kg} / \mathrm{s}]$} \\
Fuel flow & WF & 0.2628 & {$[\mathrm{~kg} / \mathrm{s}]$} \\
Combustor inlet air & W31 & 16.560 & {$[\mathrm{~kg} / \mathrm{s}]$} \\
Combustor press. loss & $\mathrm{DP}$ & 7.0 & {$[\%]$} \\
Combustion efficiency & $\eta_{b}$ & 99.99 & {$[\%]$} \\
Turbine inlet flow & W4 & 16.823 & {$[\mathrm{~kg} / \mathrm{s}]$} \\
Turbine inlet temp. & T4 & 1218.97 & {$[\mathrm{~K}]$} \\
Turbine inlet press. & P4 & 914.053 & {$[\mathrm{kPa}]$} \\
Turbine isent. efficiency & $\eta_{\text {isen-t }}$ & 92.44 & {$[\%]$} \\
Turbine polyt. efficiency & $\eta_{\text {poli-t }}$ & 90.24 & {$[\%]$} \\
Exhaust flow & W5 & 18.663 & {$[\mathrm{~kg} / \mathrm{s}]$} \\
Exhaust temperature & $\mathrm{T} 5$ & 731.18 & {$[\mathrm{~K}]$} \\
Exhaust pressure & P5 & 106.594 & {$[\mathrm{kPa}]$} \\
Exit static pressure & PS8 & 101.325 & {$[\mathrm{kPa}]$} \\
\hline Lower heating value & LHV & 48,000 & {$[\mathrm{~kJ} / \mathrm{kg}]$} \\
\hline Gearbox efficiency & $\eta_{\text {mec }}$ & 0.978 & {$[-]$} \\
Generator efficiency & $\eta_{\text {ger }}$ & 0.964 & {$[-]$} \\
\hline & & & \\
\hline
\end{tabular}


After the design point model was adjusted, the next step was to adjust the model at off-design without information of the actual component maps. Due to the unavailability of the actual component maps the approached used was to carried out the modeling at off-design conditions adopting generic maps and making appropriate adjustments, using a function named "modifier". At this point, some changes become important to adjust the generic maps to the actual ones, achieving a more accurate performance at off-design conditions. The adjustments in values of these generic maps, as pressure ratio, mass flow and efficiency, arises with the objective of reaching desired levels of power and efficiency. At the compressor map, the control parameters, named compressor capacity, do simultaneous changes of pressure ratio and mass flow along a constant beta line. For example purposes, changing the compressor capacity by $+1 \%$ will increase the mass flow by $+1 \%$ and at the same time increases the pressure ratio according to the local gradient of the auxiliary map coordinate beta.

\section{RESULTS}

At the outset, the creation procedure and verification of the design and off-design models will be showed using natural gas as fuel, after that, the results using low heating value fuels (Fuel 1 and Fuel 2) will be displayed in the following subsection.

\section{CREATION AND VERIFICATION OF THE MODEL AT DESIGN AND OFF DESIGN POINT}

In this study was adopted a generic single shaft gas turbine (GGT) designed to operate with natural gas and to generate electrical power. The model calibration process is extremely important to obtain accurate simulations data; therefore some values must be initially guessed, and improved by a trial, as part of the procedure to build a design point model. Table 3 shows the data employed to build the current design point performance model. The turbine first rotor temperature must be held to limits compatible with the local material properties, consequently cooling system is employed. The percentage of the air bled at compressor discharge was $10 \%$ of $\mathrm{W} 2$, being $4 \%$ for the NGV cooling and $6 \%$ for cooling cavities, discs, platforms, etc. For comparison purpose, the computational simulations were conducted using natural gas with a LHV equal to $48,000 \mathrm{~kJ} / \mathrm{kg}$ at ISO conditions (ISO 2533) at design point. Table 4 shows a comparison between the reference engine (GGT) and the present results at the design point, negligible deviations can be observed for all compared parameters. The model was adjusted at design point and it will be used to perform the adjustment of the model at off-design.
Table 4. Design point: comparison between the reference engine (GGT) and present result.

\begin{tabular}{cccc|c}
\hline Parameters & Units & GGT & Present Results & Deviations [\%] \\
PW & {$\left[\mathrm{kW}_{\mathrm{e}}\right]$} & $3,515.0$ & 3515.0 & 0 \\
$\mathrm{HR}$ & {$\left[\mathrm{kJ} / \mathrm{kW}_{\mathrm{e}}-\mathrm{h}\right]$} & $12,920.2$ & $12,920.2$ & 0 \\
$\eta_{\text {net }}$ & {$[\%]$} & 0.2786 & 0.2786 & 0 \\
$\mathrm{WF}$ & {$[\mathrm{kg} / \mathrm{s}]$} & 0.2628 & 0.2628 & 0 \\
$\mathrm{~T} 8$ & {$[\mathrm{~K}]$} & 731.15 & 731.2 & 0.01 \\
\hline
\end{tabular}

The gas turbine model was adjusted at offdesign conditions taking into account the variation in ambient temperature, the range adopted was from $265.65 \mathrm{~K}\left(-7.5^{\circ} \mathrm{C}\right)$ to $316.15 \mathrm{~K}\left(+43^{\circ} \mathrm{C}\right)$.

In Figure 2 (a) are shown the power output and heat rate versus ambient temperature. These results were obtained at off-design operation, after the adjustment of the model. The data in continue lines are from GGT and the points on the lines are the data from the present results, small deviations were found due to the unavailable of the actual performance maps, requiring some adjustments in the generic ones.

In Figure 2 (b) are shown the thermal efficiency and fuel flow. These results were obtained at offdesign operation, after the adjustment of the model. The data presents small deviations and the explanation made previously is still valid. Since, small deviations were found the model is considered adjusted. Now it is possible to continue the off-design analysis varying other parameters, as fuel type.

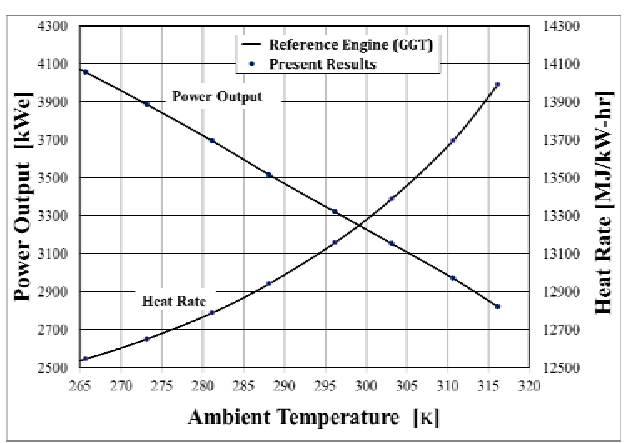

(a) Power output and heat rate

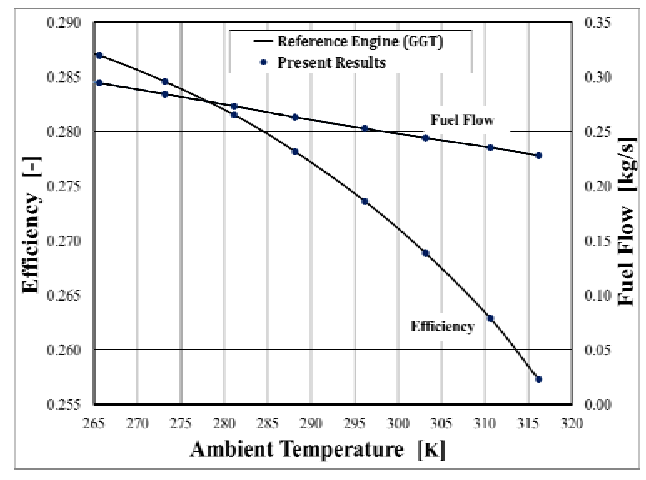

(b) Thermal efficiency and fuel flow

Figure 2. Comparison between the present results and GGT. 
In Fig. 3 it is possible to visualize the operating line excursion, in yellow, when ambient temperature is changed from $265.65 \mathrm{~K}\left(-7.5^{\circ} \mathrm{C}\right)$ to $316.15 \mathrm{~K}$ $\left(+43^{\circ} \mathrm{C}\right)$. Figure 3 a shows the running line on compressor map and Figure $3 \mathrm{~b}$ shows the operating line on turbine map. The compressor map, Figure 3 a, is represented by pressure ratio versus corrected mass flow for each constant corrected speed line. The turbine map, Figure $3 \mathrm{~b}$, is represented by expansion ratio versus corrected speed multiplied by corrected mass flow, for each constant corrected speed line. The design point is represented on compressor map at corrected speed line set as 1 , the same applies to the turbine.

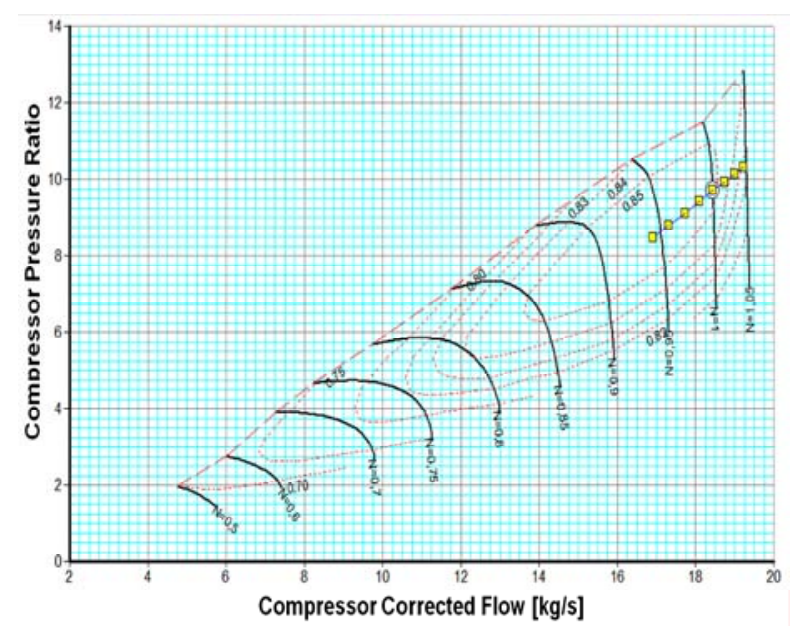

(a) Compressor map

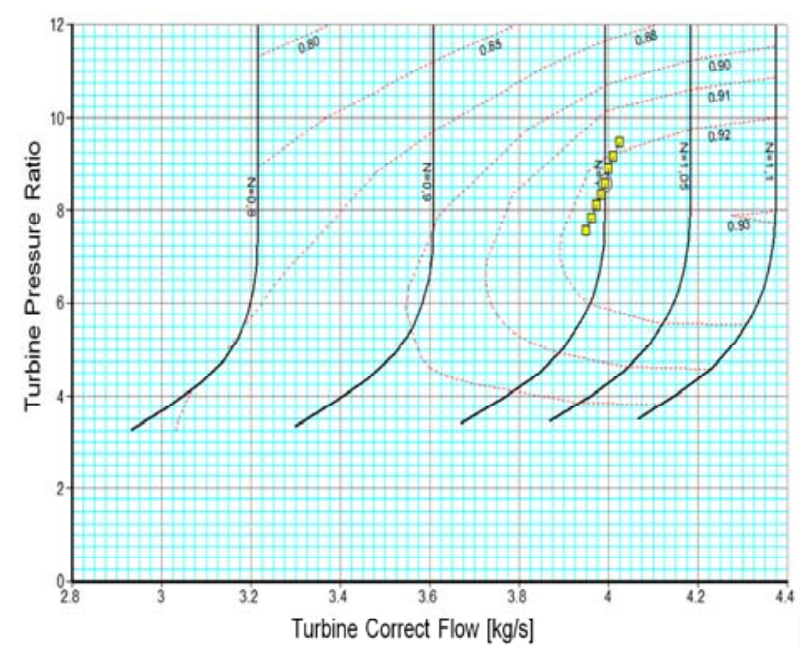

(b) Turbine map

Figure 3. Runnning line on compressor and turbine maps.

correctd speed $=N_{\text {corr }}[\%]=\frac{N / \sqrt{\frac{R \times T}{R_{\text {std }} \times T_{\text {std }}}}}{\left(N / \sqrt{\frac{R \times T}{R_{\text {std }} \times T_{\text {std }}}}\right)_{d s}} \times 100$ where, $\mathrm{N}$ is the nominal speed (rpm), $\mathrm{R}$ is the gas constant, $\mathrm{T}$ is the temperature, std indicates standard day conditions $\left(\mathrm{R}_{\mathrm{std}}=287.05 \mathrm{~J} / \mathrm{kg} \mathrm{K}\right.$ for dry air and $\mathrm{T}_{\text {std }}=288.15 \mathrm{~K}$ ), while $d s$ means design point values.

The change in ambient temperature implies a variation in compressor corrected speed line between 94.72 and $104.31 \%$, according to the Eq. (3), quoted by Kurzke (2007). The gas turbine under study is a single shaft linked to generator, therefore, when the ambient temperature changes the corrected speed line will change too, but the physical speed (in rpm) is maintained constant.

The results comparisons were made between the present results and GGT at design point and offdesign condition. The next step is to evaluate the gas turbine performance at off-design changing the fuel characteristics.

\section{PERFORMANCE EVALUATION AT OFF- DESIGN USING LOWER LHV FUELS}

The first parameter compared was the power output versus ambient temperature.

Figure 6 shows the simulation results obtained using three different fuels: Natural Gas (LHV = $48,000 \mathrm{~kJ} / \mathrm{kg})$, Fuel $1(\mathrm{LHV}=4,840.2 \mathrm{~kJ} / \mathrm{kg})$ and Fuel 2 (LHV $=5,047.1 \mathrm{~kJ} / \mathrm{kg})$. The results demonstrate that higher power output in any ambient temperature is obtained when using the lower LHV fuels. So, if the purpose is to maintain the same temperature at the combustion chamber exit, it will be necessary to increase fuel flow and consequently pressure ratio, reducing surge margin. Therefore, lower power levels are obtained using Natural Gas due to its higher calorific value, lower mass flow rate and pressure ratio. The power output has the same characteristics for all of the fuels with higher power output generated on coldest days.

Figure 5 illustrates the effect of ambient temperature over the surge margin. As can be observed, when lower LHV fuels are used, the surge margin is reduced due to the increased fuel flow and consequently increasing compressor pressure ratio. In this way, the gas turbine operation becomes hazardous owing to the proximity of the operating line to the compressor surge line. The surge margin required to a given operation depends on the transient behavior and should be within the specified limits studied during gas turbine design. In cases studied it was possible to observe that the gas turbine operating line is very near to the surge line, $5 \%$, and which may represent an unsafe operation when using lower LHV fuels. Hence, in order to improve the surge margin in all operating points it will be necessary to apply an control strategy to elevate the surge margin to an adequate limit. 


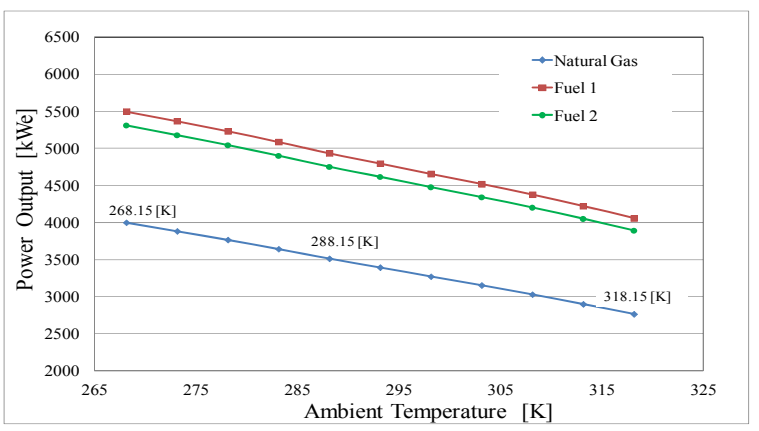

Figure 4. Power output versus ambient temperature.

Figure 6 shows the surge margin versus air bled from the compressor exit in order to recover the surge margin. The adopted strategy to recover the compressor surge margin was made to reach a similar value as when running with natural gas at design point. The simulation was made considering standard day conditions, $288.15 \mathrm{~K}$ and $101,325 \mathrm{~Pa}$, therefore maintaining constant the corrected speed line. The extracted air could be used in an industrial process, such as gasification that needs pressurized air to perform its process, but this was not considered in this work. Furthermore, the produced fuel gas by the gasifier could be burned in a gas turbine resulting in higher efficiency and lower costs.

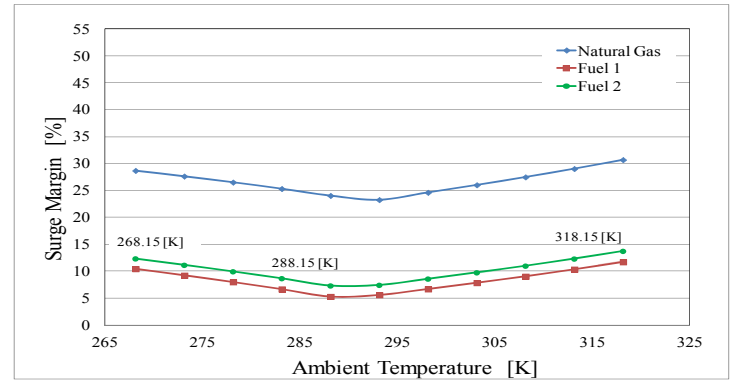

Figure 5. Surge margin versus ambient temperature.

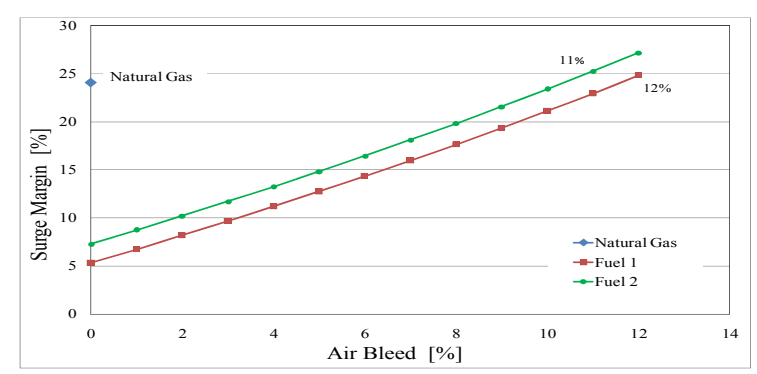

Figure 6. Surge margin versus air bled.

As a penalty the power output drastically decreases when air is bled, as can be seen in
Figure 7, reaching the same power output level as when set with Natural Gas. For the Fuel 1 when the air bled is $12 \%$ the surge margin is $25 \%$, red line in Figure 6, while for the Fuel 2 it was necessary to bled $11 \%$ for the same surge margin, green line in

Figure 6.

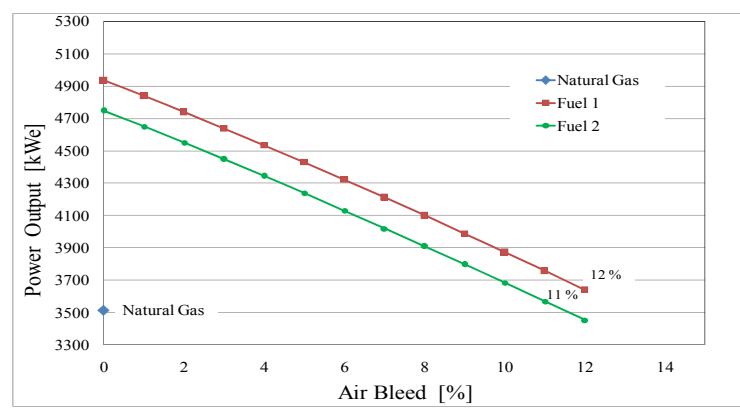

Figure 7. Power output versus air bled.

This surge margin level is almost the same set at design point for Natural Gas, the point in blue in Fig. 6. Using this strategy the surge margin was recovered, as can be seen in Figure 6 , but a penalty is observed in Fig. 7, the power output decreases. Basically, this decrease in power output is due to the fact the air bled represents a waste of energy, due to the power absorbed by the compressor to compress the air. The air bled does not perform work on the turbine, penalizing the power output.

Figure 8 shows the running line behavior, in yellow, on the compressor map. The simulation was done at constant corrected speed line. It can be seen in Fig. 8 the influence of the air bled on the surge margin for Fuel 1, from 0 to $12 \%$ from compressor inlet air flow. Increasing the percentage of the air bled the surge margin increases too and the compressor exit pressure decreases. The constant corrected speed lines are, from left to right: $0.5,0.6$, $0.7,0.75,0.8,0.85,0.9,0.95,1.0$ and 1.05 .

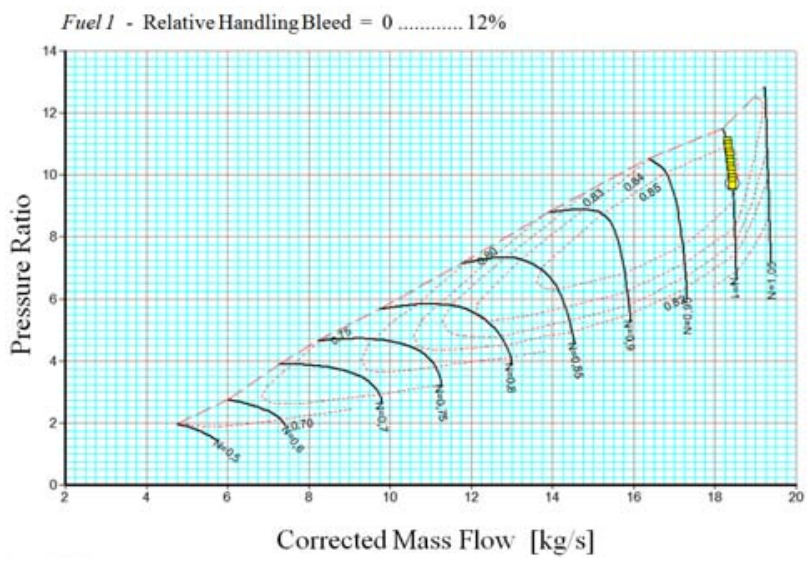

Figure 8. Running line on compressor map, Fuel 1. 
In Figure 9 is shown the surge margin as a function of the ambient temperature. The simulation was done maintaining the air bleed fixed for Fuel 1 and Fuel 2, $12 \%$ and $11 \%$ respectively, the same values found in the above study, while for Natural Gas bleed was not considered.

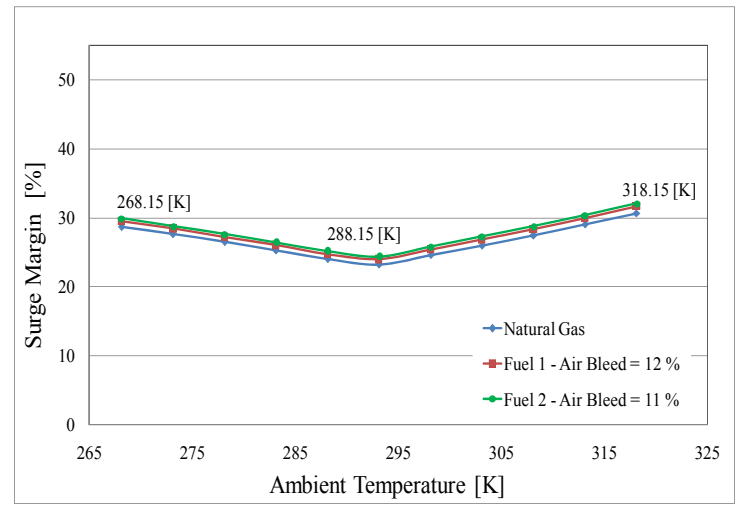

Figure 9. Surge margin versus ambient temperature for Fuel 1, Fuel 2 and Natural Gas.

As can be seen in Figure 9, the surge margin for Fuel 1 and Fuel 2 is maintained at the same level as that of Natural Gas for all ambient conditions. However, as a consequence the power output decreases due to the air bleed, as can be seen in Figure 10, and shows the same level as when using Natural Gas.

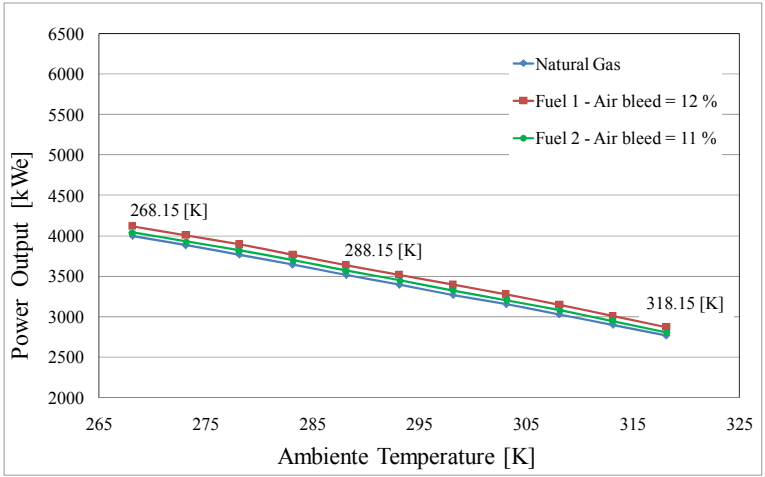

Figure 10. Power output versus ambient temperature for Fuel 1, Fuel 2 and Natural Gas.

\section{CONCLUSION}

In this work the gas turbine performance was evaluated changing the fuel. Three types of fuels were used in this study, one was the Natural Gas, considered as a standard fuel with LHV $=48,000$ $\mathrm{kJ} / \mathrm{kg}$, and the other two were Lower LHV fuels, Fuel 1 has a $\mathrm{LHV}=4,867.4 \mathrm{~kJ} / \mathrm{kg}$ and Fuel 2 has a LHV $=$ $5,266,3 \mathrm{~kJ} / \mathrm{kg}$. Firstly, the design point model was set using natural gas as a fuel. Secondly, the gas turbine model was adjusted at off-design conditions according to data available from open literature. The performance behavior at off-design was investigated using two different lower LHV fuels. It was observed that when lower LHV fuels were used there is the necessity for recovering the surge margin to ensure gas turbine safe operation. So, the control strategy adopted in this work was the air bleed from compressor exit. This strategy proved to be useful and the surge margin level was recovered for both cases when using lower LHV fuels. However, as a consequence the power output decreases due to the fact the air bled represents a waste of energy, due to the power absorbed by the compressor to compress the air. The air bled does not perform work on the turbine, penalizing the power output. The air bled could be used in industrial process, such as gasification that needs pressurized air to perform its process. Furthermore, the produced fuel gas by the gasifier can be burned in a gas turbine resulting in higher efficiency and lower costs, but this was not considered in this work.

\section{ACKNOWLEDGEMENTS}

VSE (Vale Soluções em Energia S.A.), CNPq (Conselho Nacional de Desenvolvimento Científico e Tecnológico) and CAPES (Coordenação do Aperfeiçoamento do Pessoal de Nível Superior) are acknowledged for their support to the research carried out at the Center for Reference on Gas Turbines (ITA).

\section{REFERENCES}

Baskharone, E. A., 2006, Principles of Turbomachinary in Air-Breathing Engines, Cambridge University Press.

Ernst, Y., 2011, BP Statistical Review of World Energy, BP, London, Review 2010, pp. 45.

Higman, C., and Van der Burgt, M., 2007, Gaseification, Second Edition, San Francico.

ISO 2533, International Organization for Standardization, Standard Atmosphere.

Kurzke, J., 2007, GasTurb 11: A Program for Calculating Design and Off-Design Performance of Gas Turbines, Germany.

Palmer, C. A., Erbes, M. R., and Pechtl, P. A., 1993, Gatecycle Performance Analysis of the LM2500 Gas Turbine Utilizing Low Heating Value Fuels, ASME COGEN-TURBO.

Palmer, C. A., and Erbes, M. R., 1994, Simulation Methods used to Analyze the Performance of the GE PG6541B Gas Turbine Utilizing Low Heating Value Fuels, ASME COGENTURBO POWER, Portiland, Oregon.

Palmer, C. A., Erbes, M. R., and Pechtl, P. A., 1993, Gatecycle, Performance Analysis of the LM2500 Gas Turbine Utilizing Low Heating Value 
Fuels, International Gas Turbine Institute, ASME Cogen Turbo 1993, Vol. 8.

Saravanamuttoo, H. I. H., Rogers, G. F. C., and Cohen, H., 2001, Gas Turbine Theory, 5th Edition, Pearson Education Limited.

Solar Turbines, 2009, Centaur 40, Gas Turbine Generator Set. Solar Turbines Inc., San Diego, CA.

Walsh, P. P., and Fletcher, P., 2004, Gas Turbine Performance, 2nd Edition, Blackwell Science Ltd. 